\title{
The Rohingya Muslims in Myanmar are Victim of Genocide!
}

\section{Haradhan Kumar Mohajan}

Faculty of Business Studies, Premier University, Chittagong, BANGLADESH

*Corresponding Contact:

Email: haradhan1971@gmail.com

\begin{abstract}
This article deals with the genocide against the Rohingya Muslims in Myanmar. For decades, the Rohingya in Myanmar has been the victim of the extensive violation of human rights. Recently the Rohingya, Karen, San, Chin, and other ethnic groups are facing ethnic cleansing in Myanmar. Of them, the Rohingya is the mostly dehumanized and persecuted ethnic minority group. The Rohingya is stateless and exile in its own country. The Government of Myanmar (GoM) has taken attempts for establishing one nation, one language, and one religious policy in the country. Since 2012 the persecution upon the Rohingya in Myanmar falls in the genocide. In 1917, the Rohingya faced the final stages of genocide. Genocide is considered as one of the worst moral crimes a Government can commit against its citizens. An attempt has been taken here to discuss the aspects of genocide, and genocide upon the Rohingya Muslims in Myanmar.
\end{abstract}

Keywords: Ethnic cleansing, genocide, human rights, the Rohingya

$9 / 22 / 2018$

Source of Support: Nil, No Conflict of Interest: Declared

This article is is licensed under a Creative Commons Attribution-NonCommercial 4.0 International License.

Attribution-NonCommercial (CC BY-NC) license lets others remix, tweak, and build upon work non-commercially, and

although the new works must also acknowledge \& be non-commercial.

\section{INTRODUCTION}

About 10 to $20 \%$ of the world's populations (1.2 billion) live as minorities apart from their homeland (UN Guide for Minorities, 2017). At present different types of violence and war are taking place around the globe. As a result, illegal migrations become big problems in most of the countries. The Rohingya is an ethnic Sufi-Sunni Muslim minority that lives in Rakhine (formerly Arakan) State of Myanmar. The Rohingya becomes one of the most persecuted minorities in the world. Recently the Rohingya persecution in Myanmar becomes the highest, and more than 1.1 million Rohingya have migrated in Bangladesh (Kiragu et al., 2011).

Myanmar is the ethnically diverse country of Southeast Asia. Its capital city is Naypyidaw (former Yangon), and the official language is Burmese. Its estimated populations are to be $60,584,650$, and the total area is 261,228 square miles (Demographics of Myanmar, 2018). It borders in the south with the Bay of Bengal, the Andaman Sea, in the northeast with China, in the east with Laos, in the southeast with Thailand, with Bangladesh in the west, and India in the northwest (Figure 1) (CIA, 2013). 


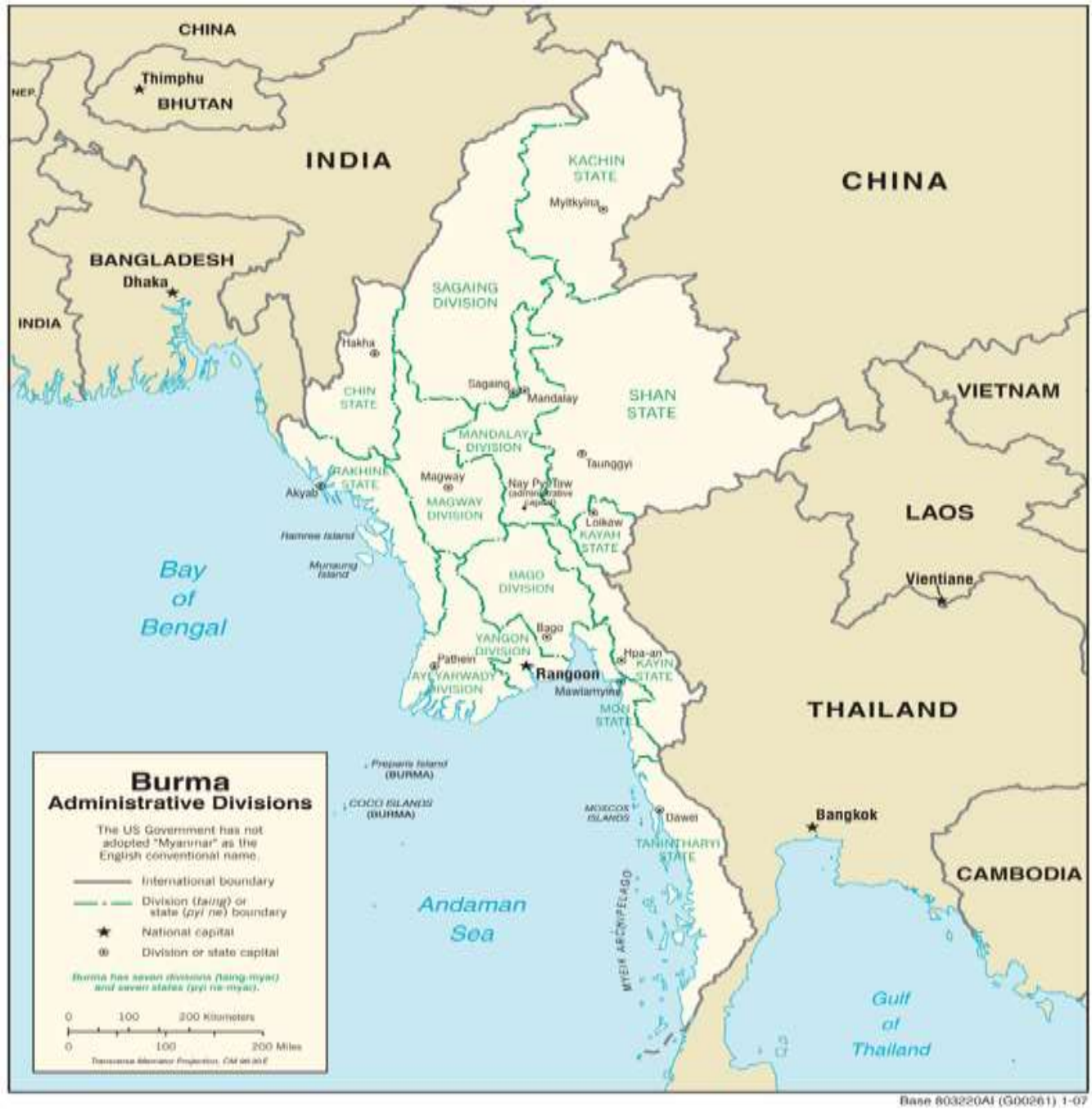

Figure 1: The Administrative map of Myanmar

Rakhine (Arakan) is a State located in the west coast of Myanmar which is one of the poorest regions of the country. Its area is 14,200 square miles (Islam, 1999). In Rakhine, it is estimated that $59.7 \%$ of the 3.8 million people are Buddhist, $35.6 \%$ are the Rohingya, and the remainder is from other religious groups (Alam, 2013). The Rohingya has its distinct ethnicity with own language and culture, and a long historical connection to Rakhine State (Ullah, 2011). The 1982 Citizenship Law has been denied Burmese citizenship of the Rohingya. Under this law, the Rohingya was not recognized as one of the country's 135 ethnic groups (Abdelkader, 2014).

In the 1990s, Myanmar passed a law that required all people in Rakhine to gain permission before obtaining marriage licenses. Because GoM claimed that the Rohingya population is reproducing faster than international standards. To achieve marriage licenses men need to shave their beards and prohibit women from wearing religious head and face coverings for their license photographs. The Rohingya women required to take pregnancy tests before issuing marriage permits (Fortify Rights, 2015). 


\section{LITERATURE REVIEW}

International Development Committee has recommended for the solution of the Rohingya crisis. It has also discussed the oppression of the Rohingya in Myanmar (International Development Committee, 2018). Haradhan Kumar Mohajan has indicated that more than one million Rohingya have migrated in Kutupalong-Balukhali, and Nayapara refugee camps, respectively, in Ukhia, and Teknaaf of Cox's Bazar district of Bangladesh. The Government of Bangladesh has provided shelter, food, clothes, treatment, and other humanitarian aid to these Rohingya migrants (Mohajan, 2018).

Christina Szurlej has analyzed the aspects of genocides against the Rohingya Muslims of Myanmar. She demonstrates in some details how the Rohingya faces an acute risk of genocide. She also describes ten stages of genocide efficiently (Szurlej, 2015). Alina Lindblom and her coauthors have found persuasive evidence that the crime of genocide has been committed against the Rohingya in Rakhine State. They have demanded the independent investigation and keen protection of the Rohingya. They have examined and analyzed a variety of primary sources, including testimonies from the Rohingya, internal Myanmar government documents, and anti-Rohingya propaganda flyers produced by Rakhine monks and politicians (Fortify Rights, 2015). Eleanor Albert has ascertained that tens of thousands of Rohingya left Myanmar to neighboring countries (Albert, 2017).

Linda Crossman analyzes the violation of human rights against the Rohingya in Myanmar. She stresses that the policies and actions against the Rohingya since 2012 are ethnic cleansing and the beginning of genocide (Crossman, 2014). The term ethnic cleansing, which is not a formal legal term, first appeared in describing acts carried out during the conflicts in former Yugoslavia (The Human Rights Council, 2017). Maung Zarni and Alice Cowley have indicated the persecution on ethnic Rohingya of Myanmar is called slowburning genocide over the past 35 years (Zarmi \& Cowley, 2014).

Daniel Feierstein has outlined the six stages of genocide as; i) stigmatization and dehumanization, ii) harassment, violence, and terror, iii) isolation and segregation, iv) systematic weakening, v) mass annihilation and vi) removal of the victim from the society (Feierstein, 2014). The Rohingya has already suffered the first four of the six stages of genocide. It has been stigmatized, dehumanized, discriminated, harassed, terrorized and slaughtered by the GoM, Myanmar defenses, and Rakhine people. They have been isolated and segregated into internally displaced persons (IDP) camps, and securitized areas (Green et al., 2015).

\section{ObJectives OF The Study}

In the study, we take attempts to discuss the genocide that performed by the Myanmar authority. Some other objectives of the study are to:

- provide the meaning of genocide,

- show the historical evidence of genocide,

- highlight the stages of genocide,

- discuss the violation of human rights in Myanmar, and

- provide the proof of genocide in Myanmar.

\section{Methodology OF the Study}

According to C. R. Kothari research methodology is the systematic procedure adopted by researchers to solve a research problem that maps out the processes, approaches, 
techniques, research procedures, and instruments (Kothari, 2004). This article tries to describe genocide on the Rohingya in the Rakhine State of Myanmar. In the study, we have used secondary data to prepare the paper. The data are collected from books and journals of various authors, theses, magazines, newspapers, websites, public records and statistics, historical documents, and various research reports.

\section{MeAning OF Genocide}

Genocide is an act to demolish a national, ethnic, racial, or religious group in whole or in part (UN, 1948; Schabas, 2009). Polish Jewish lawyer Raphael Lemkin (1900-1959) coined the term 'genocide' in 1944, in a book, Axis Rule in Occupied Europe, documenting Nazi policies of systematically destroying national and ethnic groups, including the mass murder of European Jews. He combined the Greek word genos (race or tribe) with the Latin word cide (to kill) to indicate hybrid word 'genocide' (Lemkin, 1944). Rudolph J. Rummel created the term democide to include assaults on political groups (Rummel, 1998).

On 9 December 1948, genocide is approved and proposed the Convention on the Prevention and Punishment of the Crime of Genocide (CPPCG) which came into effect in January 1951 (OHCHR, 1951). Article 2 of the CPPCG, defines the genocide as follows (Charny, 1999): "The acts committed with intent to destroy, in whole or in part, a national, ethnical, racial or religious group, as such; a) Killing members of the group, b) Causing serious bodily or mental harm to members of the group, c) Deliberately inflicting on the group conditions of life calculated to bring about its physical destruction in whole or in part, d) Imposing measures intended to prevent births within the group; e) Forcibly transferring children of the group to another group". Also, conspiracy to commit genocide, direct and public incitement to commit genocide, attempt to commit genocide, complicity in genocide are included in the area of genocide. Genocide is considered an international crime that may be indicted, tried, and punished by the International Criminal Court (ICC) (Rummel, 2007).

\section{Crimes against Humanity}

Any act when committed as part of a widespread or systematic attack directed against any civilian population is considered as crimes against humanity. Article 7 of the CPPCG defines crimes against humanity, listed 16 individual crimes as (ICC, 2011): 1) murder, 2) extermination, 3) enslavement, 4) deportation or forcible transfer of population, 5) imprisonment, 6) torture, 7) rape, 8) sexual slavery, 9) enforced prostitution, 10) forced pregnancy, 11) enforced sterilization, 12) sexual violence of comparable gravity, 13) persecution against any identifiable group or collectivity on political, racial, national, ethnic, cultural, religious, gender, etc., 14) enforced disappearance of persons, 15) the crime of apartheid, and 16) inhuman activities that cause great suffering or serious injury to body or mental or physical health.

\section{Historical Evidence of Genocide}

The genocide and mass-murder by the Governments are called democide. In the $20^{\text {th }}$ century about 174 million people are murdered by the governments; about 110 million people by the communist governments ( 62 million are killed by Lenin, Stalin, and their successors; and 35 million by Mao Tse-tung of China), Hitler's Germany has murdered 21 million, and Chiang Kai-shek's Nationalist government of China murdered about 10 million. The rest incidents are; Khmer Rouge Cambodia (1975-1979: 2 million), Japan (1937-1945: 6 million), North Korea (1948-2002: 2 million), Mexico (1900-1920: 1.4 million), 
Turkey (1909-1918: 1.9 million), Pakistan (1958-1987: 1.5 million), Poland (1945-1948: 1.6 million), Russia (1900-1917: 1.1 million), Vietnam (1945-1987: 1.7 million), and Tito's Yugoslavia (1944-1987: 1 million) (Rummel, 2007; Jones, 2010).

But not all of these killings are genocides. Historically the genocides are considered as follows (Andreopoulos, 1997; Totten et al., 1997; Gellately \& Kiernan, 2003):

- During World War II, the Holocaust (from the Greek hólos, 'whole' and kaustós, 'burnt') costing 5-6 million Jews were killed by the influence of General Adolf Hitler.

- In 1994, about 500,000-750,000 Tutsi were killed in Rwanda.

- In the 1990s, 25,000-100,000 murdered for the ethnic cleansing in Bosnia-Herzegovina of Yugoslavia.

- During 1909-1923, about 2.1 million Armenians, and 347,000 Greeks were killed by the Turkish government.

- Cambodian Khmer Rouge during 1975-1979, murdered about 541,000 Buddhist monks, Cambodian-Vietnamese, Muslims, and other minorities.

- During 1904-1907, German killed 72,000 Hereros, Hottentots, and Berg-Damaras of Namibia.

- $\quad$ During 1967-1987, Burundi murdered 150,000 Hutus.

- During World War II, Croatia murdered 655,000 Serbs and Jews.

- During 1966-1988, Dictator Saddam Hussein of Iraq murdered over 100,000 Kurds and southern Shiites.

- Stalin's forced during 1932-1933 famine in Ukraine that murdered about 5 million to eliminate disbelievers from communist society.

- In 2015, Communist China killed 375,000 Tibetans, Sinkiang Muslims, and other minorities.

- In 1971, West Pakistan murdered more than one million Bengali leaders, intellectuals, professionals and Hindus in East Pakistan (now Bangladesh).

- In 1965, Indonesia murdered 509,000 communists and ethnic Chinese, and during 1975-1998 murdered more than 150,000 in East Timor.

- Since 1955 Sudan murdered one million Southern Christians and Black.

- Since 1942 the Myanmar military has been carrying out ethnic cleansing against the Rohingya and other ethnic groups.

\section{StAGES OF GENOCIDE}

In 1998, Professor Gregory Stanton, President and Co-Founder of Genocide Watch, has developed eight stages of genocide to assess the risk of an outbreak as (Stanton, 2013); i) classification, ii) symbolization, iii) dehumanization, iv) organization, v) polarization, vi) preparation, vii) extermination and viii) denial. Five years later, he expanded these eight stages to ten, by adding discrimination at stage three and persecution at stage eight.

Classification: It develops distinctions between two groups based on ethnicity, race, religion, or nationality. In Myanmar, the Rohingya is classified as non-citizen and separated from other ethnic groups (Szurlej, 2015).

Symbolization: It provides ways to identify the groups. It is a distinction between two religious and ethnic groups; one group is hated and tortured with dehumanization activities, and other is not treated so. In Myanmar, the Rohingya are symbolized as Bengali settlers and illegal immigrants by denying their legal citizenship. The Rohingya are also called Muslim “Kalar” which means black (Fortify Rights, 2015). 
Discrimination: It denies civil rights, voting rights, and citizenship of a religious group. According to the 1982 Citizenship Law, the Rohingya lost their citizenship and became stateless. Consequently, they have denied government jobs, healthcare, education, and confiscation of land and property (HRW, 2013).

Dehumanization: It is the activity that compares the target group with animals, insects, or diseases. In Myanmar, the Buddhist monks who are part of the 969 Movement call the Rohingya snakes, mad dogs, wolves, jackals, and African carp; also indicate them as jihadists, terrorists, murderers, and thieves. These are inhuman activities against the Rohingya ethnic minority (HRW, 2013).

Organization: In Myanmar, the organization includes; the 969 movement, extremist orders of monks, the Tatmadaw, and police. Their activities against the target group the Rohingya include murders and disappearances, torture, arrests, mass rapes, and arson of the Rohingya villages. Sometimes the Rohingya women have died due to gang-rapes (Fortify Rights, 2015).

Polarization: To polarize the target group, the stronger group uses hateful propaganda. An attempt always acts to create a gap between the two groups. Sometimes black laws enacted to forbid social interaction between the polarized groups. During Thein Sein period GoM fears of the growing population of Muslims. In May 2015, the Burmese authority restricted marriages between Buddhist women and non-Buddhist men. The Rohingya need permission from the State before getting marriage and they are restricted to having only two children (Fortify Rights, 2015).

Preparation: In the preparatory step, perpetrators plan for ethnic cleansing, purification, or counter-terrorism of the targeted group. The GoM has trained troops, strengthen armies, and procure heavy weapons against the Rohingya (Szurlej, 2015).

Persecution: In persecution stage, members of the target group are separated from the general populace based on ethnicity and religion, and transferred them to ghettoes, concentration camps, or barren regions. The target group often loses their property to the government through expropriation. Acts of genocide occur at this stage when part of the group is intentionally destroyed (Hodal, 2013). The Rohingya is removed from homes, and are forced them into camps for internally displaced persons (IDP) in Rakhine State where there is lack of adequate food, water, and shelter, as well as access to medical care and education (Fortify Rights, 2015).

Extermination: In this stage, mass killings take place that reflects the perpetrators' dehumanization of their victims. This activity is perpetrated by State officials, armed groups, or the dominant group as a whole. From 2012 to 2016 over 1,000, and in 2017, at least 10,000 Rohingya, including children and infants had died. Starvation and death from disease in IDP camps, especially of children and the elderly, have cost thousands of lives. In brief, the Rohingya has lost its full rights to study, work, travel, marry, practice religion, and access to health services (Wright \& Westcott, 2017).

Denial: In this final stage, genocidal perpetrators attempt to deflect blame onto victims, by hiding or destroying evidence, opposing investigations, and intimidating witnesses. If they are unsuccessful for suppressing evidence, actively deny their roles in inciting, conspiring, organizing, and committing genocide. The GoM denies all the inhuman activities against the Rohingya (Wagley, 2014). 


\section{Violation of Human Rights in MyanmaR}

Human rights are vital items in democracy and are related to the development of a country. In a country, if human rights are violated, then the country cannot be developed, and the democracy of it becomes weak. Human rights are secure in a democratic country rather than a country which is foreign domination or military regimes or authoritarian dictatorships or one-party rule (Mohajan, 2013). There are systematic violations of civil, political, economic, social, and cultural of human rights in the Rakhine State of Myanmar are as follows (Veen, 2005):

- rape and other forms of sexual violence,

- extra-judicial killings,

- forced labor and child labor,

- destruction of livelihoods,

- confiscations of land,

- the continuing use of torture,

- renewed instances of political arrests and continuing detentions,

- forced relocation,

- discrimination and persecution,

- human trafficking,

- denial of freedom of assembly, association, expression, and movement,

- lack of independence of the judiciary,

- unsatisfactory conditions of detention,

- systematic use of child soldiers,

- violations of the right to an adequate standard of living, etc.

\section{Genocides in MyanmaR}

The acts committed against the Rohingya constitute genocide that intent to destroy, in whole or in part, the Rohingya group. According to the definition of genocide, the Rohingya are the victim of genocide. It is clear that the political and social situations in Myanmar are very terrible. Fortify Rights, and the Simon-Skjodt Center continue to be seriously concerned about growing evidence of genocide against the Rohingya (Fortify Rights, 2015). The Myanmar security forces have deliberately targeted the destruction of the Rohingya civilian populations including women, men, children, whole families, and all villages (AI, 2017).

Soldiers and knife-wielding civilians of Myanmar hacked to death and slit the throats of the Rohingya men, women, and children were burned alive. The Tatmadaw, NaSaKa, Police, and the Rakhine villagers have raped, gang-raped, and sexually assaulted the Rohingya women and girls. Some women have died as a result of gang-rapes. The GoM imposes strict restrictions on the freedom of movement of the Rohingya. They have to pay the requisite fees and bribes to find permission of movement to travel among townships. To control the Rohingya population GoM imposes restrictions on the marriage, and childbirth as a two-child policy (HRW, 2013). The oppression of the Rohingya has started from the British period. There were some massacres before 2012. But the strategy of ethnic cleansing of the Rohingya has reached the level of genocide since 2012. The Rohingya has lost the security of lives, free from hunger, disease, arbitrary detention, and physical abuse (Khin, 2014). According to Maung Zarni and Alice Cowley, this kind of genocide has been defined as "slow-burning" (Zarmi \& Cowley, 2014). But the fifth term of Article 2 of the CPPCG in the definition of genocide; it has not been found any evidence that children of 
the Rohingya have been transferred to other groups. Some oppressions and persecutions against the Rohingya from 1242 to 2018 are given as follows:

\section{Arakan Massacres in 1942}

The Rohingya and the Rakhine had been peacefully coexisting in Arakan over the centuries. Unfortunately, the relation between these two communities became bitter by the war between Japanese and British forces (Ullah, 2011). During World War II, under British colonial rule, Japanese forces attacked Burma. Then the Commander-in-Chief of British forces in Delhi, Wavell, established 'V-Forces' which armed local Rohingya in northern Arakan to create a safer zone and protect Japanese forces. But the Rohingya tried to destroy the collaborationist Arakanese villages instead of resisting the Japanese (Slim, 2009). In 1942, Muslims from Northern Rakhine State killed about 20,000 Rakhine, including the Deputy Commissioner U Oo Kyaw Khaing. In response, the Buddhist killed about 40,000 Rohingya. But, total death and destruction of wealth on both sides in 1942 conflict were not sure, and no official documents were found (Chan, 2005). Japanese forces slaughtered, raped, and tortured the Rohingya. About 40,000 Rohingya eventually fled to Chittagong Division of Bangladesh (Adelman, 2008).

\section{Oppression in the 1980s}

In 1978, a wide-scale census operation known as Nagamin (Dragon King) supposedly intended to clear out illegal immigrants. A brutal operation has performed by the GoM with the destruction of mosques and historical schools of Islamic monuments. The Government forces apply brutality, rape, starvation, torture, and murder of 50 Rohingya; which compelled to exodus more than 200,000 Rohingya from northern Arakan to Bangladesh. More than 12,000 migrants had died of starvation. The crackdown was accompanied by wide-range human rights violations against the Rohingya, such as unlawful killings, rape, and destruction of property (Grundy-Warr \& Wong, 1997; Smith, 2006).

\section{Oppression in the 1990s}

During 1991-1992, about 260,000 Rohingya fled from Myanmar, and arrived in Bangladesh, which is the second mass exodus in 15 years, that lived in temporary camps. About 230,000 Rohingya migrants have returned to the Rakhine State from 1993 to 1997 (Grundy-Warr \& Wong, 1997; Coutts, 2005).

\section{Oppression in 2001 and Onwards}

In May 2001, anti-Muslim riots broke out in the town of Taungoo in the Bago Division between Yangon and Mandalay. In the riots mosques, Muslim businesses, and residences were destroyed. An estimated ten Muslims and two Buddhists were killed in that incident (Veen, 2005). In 2001, anti-Muslim riots across Myanmar affected Rakhine State and led to the displacement of the Rohingya (HRW, 2012). After 2001, GoM has confiscated Rohingya lands and forced the Rohingya to relocate within the country. Between 2008 and 2009, at least 6,000 Rohingya have attempted the journey by sea to Malaysia and Thailand. In 1982, GoM enacted a new citizenship law that deprives the Rohingya of their citizenship which became xenophobia against the Muslim minority. As a result, the Rohingya became stateless. The Rohingya is engaged forcibly in construction work, agricultural work, portering, or serving as guards. If anybody refused to perform forced labor, he had been killed by the Tatmadaw and NaSaKa (Fortify Rights, 2015). From January to June 2014, more than 6,000 Rohingya adults and more than 2,000 children were forced to work for the Myanmar authorities in northern Rakhine State (International Crisis Group, 2016). 


\section{Persecution in 2012}

On May 28, 2012, Thida Htwe, a 27-year-old Buddhist woman was allegedly raped and murdered by three Muslim men in Ramri Township, in southern Rakhine State, which once again set off the conflict of the region. In response, about 100 Rohingya were killed (including 10 Muslim pilgrims traveling on a bus in Toungop), and 120,000 were displaced. Many dead bodies either burned or disappeared during the persecution (HRW, 2012; Mohajan, 2018). In Yan Thei village in Mrauk-U Township, about 70 Rohingya are killed (HRW, 2013). In 2012, the inter-communal conflict led to the total death of about 240 Rohingya, including children, and the total displacement of 140,000 in different Internally Displaced Persons (IDP) camps in Rakhine State where they lived in inhumane conditions. Health aid does not exist, and humanitarian aid groups are restricted to access in IDP camps. They have no safe water or sufficient latrines in IDP camps (HRW, 2012; Motlagh, 2014). In 2012, the actions, and inactions of the GoM provided concrete evidence of ethnic cleansing and genocide policies against the Rohingya (Crossman, 2014).

\section{Persecution in 2014}

In August 2014, about 87,000 Rohingya had fled from Rakhine State to Bangladesh by boat through the Bay of Bengal, and about 200 people had died in this incidence (International Development Committee, 2018).

\section{Persecution in 2015}

The UN Office for the Coordination of Humanitarian Affairs reports that more than 143,500 Rohingya remain internally displaced in Rakhine as of August 2015 (UNOCHA, 2015). In May 2015, about 139 graves suspected to be the Rohingya from Myanmar were discovered on the Thai-Malaysian border (Pitman \& Gecker, 2015).

\section{Persecution in 2016}

On 9 October 2016, about 400 Rohingya militants attacked three Border Guard Police (BGP) posts in Maungdaw and Rathedaung; killed nine police officers, and stole 10,000 rounds of ammunition and 62 firearms. They have also killed 4 Myanmar soldiers during 10-12 October 2016 (International Crisis Group, 2016). From 2012 to 2016 in Rakhine State at least have been taken over 1,000 lives, and have internally displaced over 140,000 Rohingya (Arnold, 2016). In 2016, the Tatmadaw has been accused of wide-scale human rights violations, including extrajudicial killings, gang-rapes, arson, and infanticides. But the GoM has denied the incident. On November 12, a lieutenant colonel was killed and had been injured several others by 60 armed members of the Rohingya militants. After this incident security forces destroyed 1,500 Rohingya buildings and helicopters fired indiscriminately into the Rohingya villages. More than 100 Rohingya had died, and more than 90,000 had fled from Myanmar (International Crisis Group, 2016).

\section{Persecution in 2017}

On August 25, 2017, the Arakan Rohingya Salvation Army (ARSA) attacked 30 security camps in Rakhine State and killed about 12 Myanmar police officers, and one Tatmadaw man. In this incident GoM, for the first time declared the ARSA a terrorist organization. The Tatmadaw also deployed more than 70 battalions (about 30,000-35,000 soldiers) into Rakhine State and launched clearance operations. More than 620,000 Rohingya refugees have fled to Bangladesh since 25 August 2017, and took shelter in established refugee camps in Cox's Bazar (Martin, 2017; Mohajan, 2018). The UN has described it as a 'textbook example of ethnic cleansing' (UN News Centre, 2017). 
On 27 August 2017 there was a mass-killing of Rohingya by the Myanmar Army and Rakhine collaborators in the village of Gu Dar Pyin in the Rakhine State of Myanmar, which is known as the Gu Dar Pyin massacre. Locally it is estimated that up to 400 people were killed in that massacre (Blumberg, 2018). Myanmar soldiers began burning corpses with acid and loading them onto three trucks heading for the cemetery (Klug, 2017).

On 30 August 2017, there was a mass-killing of Rohingya in Tula Toli village of Rakhine State, which is known as the Tula Toli massacre (The Guardian, 2017). It is unofficially identified that about 500 women and children were killed in this incidence (Dhaka Tribune, 2017). On 2 September 2017, the Myanmar Army and Rakhine collaborators killed more than 10 Rohingya in Inn Din village of the Rakhine State of Myanmar, which is known as the Inn Din massacre (Lone et al., 2017; Taylor, 2018). In a recent report, Médecins Sans Frontières (MSF), in English, Doctors Without Borders, reveals that from the surveys of refugees in Bangladesh, at least 9,000 Rohingya, including 730 children under-5 were killed up to 14 December 2017 in Myanmar (International Development Committee, 2018).

In 2017, at least 10,000 Rohingya, including children and infants had died. Dozens of Rohingya drowned when their ill-equipped, overloaded boat capsized in rough waters. At least 354 Rohingya villages in Rakhine State destroyed, many Rohingya houses are looted, and widespread gang-rapes were committed (Wright \& Westcott, 2017). According to the UN reports, as of January 2018, about 690,000 Rohingya had fled from the Rakhine State (Al Jazeera, 2018).

\section{Persecution in 2018}

More than 1.1 million Rohingya have migrated in Bangladesh, 133,263 in Malaysia, 102,553 in Thailand, 40,000 in India, 55,000 in Pakistan, and 1,000 in Indonesia by the end of March 2018 (International Development Committee, 2018).

\section{The Annan Commission Report}

It is an attempt towards a peaceful, fair and prosperous future for the people of Rakhine State. In September 2016, the Kofi Annan Foundation and the Office of the State Counselor (Aung San Suu Kyi) established an Advisory Commission on Rakhine State to identify the factors that have resulted in violence, displacement, and underdevelopment. The Commission has recommended the following (Advisory Commission on Rakhine State, 2017):

- A review of the 1982 Citizenship Law is needed for non-discriminatory to ensure the citizenship for all citizens, and to confiscate the law which denies rights of citizenship to the Rohingya.

- Ensure freedom of movement for all citizens in Rakhine State.

- Ensure equal access to education, irrespective of religion, ethnicity, race, gender, or citizenship status. The GoM should focus on equal access in education; improve quality of education, and upgrade of physical facilities and teaching material.

- Should close all IDP camps, and until they can be closed to ensure improved shelter, livelihoods, water and sanitation, and education within camps.

- Ensure full and unimpeded humanitarian access for all communities in Rakhine State. The Government should ensure do-no-harm, impartiality, non-discrimination, protection from physical and psychological harm, and recognition of rights and access to remedies. 
- The GoM should increase and improve its public communication, related to developments in Rakhine State.

- Ensure equal access to health treatment for all communities by including township hospitals, sub-station hospitals, rural health centers, and sub-health centers.

- The GoM should facilitate the registration process for civil society organizations from all ethnic and religious groups.

- Inter-communal dialogue should initiate at all levels. The dialogue process should be from grassroots participation, including women, youth, minorities, and civil society.

- Human right training is needed for security personnel. The GoM should take various steps to improve the monitoring of the performance of security forces.

- The GoM should list and protect historic, religious and cultural sites of all communities in Rakhine State.

\section{CONCLUSION}

The Rohingya has had a long presence in Arakan. The acts committed against the Rohingya, individually and collectively, meet the criteria for finding acts enumerated in the Genocide Convention. In this study, we have tried to show the aspects of persecutions on the Rohingya in the Rakhine State of Myanmar. By the persecutions, we have indicated that these oppressions fall in the category of genocide. In the study, we have tried to provide the definition of genocide and the stages of genocide to compare the oppressions on the Rohingya fall on the genocide or not. Finally, we have reviewed the recommendations of the Annan Commission for the welfare of the Rohingya.

\section{REFERENCES}

Abdelkader, E. (2014). Myanmar's Democracy Struggle: The Impact of Communal Violence upon Rohingya Woman and Youth. Pacific Rim Law \& Policy Journal, 23(3), 511-542.

Adelman, H. (2008). Protracted Displacement in Asia: No Place to Call Home. Ashgate Publishing Ltd.

Advisory Commission on Rakhine State (2017). Towards a Peaceful, Fair and Prosperous Future for the People of Rakhine. Final Report of the Advisory Commission on Rakhine State.

Al Jazeera (2018). Myanmar: Security Forces Face 'Action' over Killings. Al Jazeera News. 12 February 2018.

Alam, M. A. (2013). Historical Background of Arakan. Kaladen Press.

Albert, E. (2017). The Rohingya Migrant Crisis. Council on Foreign Relations, 1-6. http://www.cfr.org/burmamyanmar/rohingya-migrant-crisis/p36651

Amnesty International, AI (2017). Caged Without a Roof. Apartheid in Myanmar's Rakhine State. Amnesty International Ltd., London, UK.

Andreopoulos, G. J. (1997). Genocide: Conceptual and Historical Dimensions. University of Pennsylvania Press.

Arnold, K. (2016). Myanmar's Shame: Living inside Rohingya Ghettos, March 31, 2016, http:/ / www.cnn.com/2016/03/31/asia/myanmar-rohingya-camp/

Blumberg, A. (2018). Mass Graves Suggest Systematic Killing of Rohingya in Myanmar. 1 February 2018, HuffPost Canada.

Central Intelligence Agency, CIA (2013). The World Factbook. East and South East Asia: Burma.

Chan, A. (2005). The Development of a Muslim Enclave in Arakan (Rakhine) State of Burma (Myanmar). SOAS Bulletin of Burma Research, 3(2), 396-420.

Charny, I. W. (Ed.) (1999). Encyclopedia of Genocide, Vol. 1-2. Santa Barbara, California.

Coutts, E. (2005). The Rohingya Refugee Situation in Bangladesh. American International School. 
Crossman, L. (2014). Myanmar's Rohingya Refugees the Search for Human Security. Master Thesis, Georgetown University, Washington, DC.

Demographics of Myanmar (2018). Population of the Republic of the Union of Myanmar in 2018.

Dhaka Tribune (2017). There is No Rohingya Left in Tulatoli. Dhaka Tribune, 9 September 2017.

Feierstein, D. (2014). Genocide as Social Practice: Reorganising Society under the Nazis and Argentina's Military Juntas. New Brunswick, NJ: Rutgers University Press.

Fortify Rights (2015). Persecution of the Rohingya Muslims: Is Genocide Occurring in Myanmar's Rakhine State? A Legal Analysis, Yale Law School.

Gellately, R., \& Kiernan, B. (2003). The Spectator of Genocide: Mass Murder in Historical Perspective. Cambridge, UK: Cambridge University Press.

Green, P., MacManus, T., \& de la Cour Venning, A. (2015). Countdown to Annihilation: Genocide in Myanmar. London: International State Crime Initiative.

Grundy-Warr, C., \& Wong, E. (1997). Sanctuary under a Plastic Sheet-The Unresolved Problem of Rohingya Refugees. IBRU Boundary and Security Bulletin. Autumn, 79-91.

Hodal, K. (2013). Buddhist Monk Uses Racism and Rumors to Spread Hatred in Burma. The Guardian, April 18, 2013, http://www.theguardian.com/world/2013/apr/18/buddhist-monk-spreadshatred-burma

HRW (2013). All You Can Do is Pray: Crimes against Humanity and Ethnic Cleansing of Rohingya Muslims in Burma's Arakan State. https://www.hrw.org/report/2013/04/22/all-you-can-dopray/crimes-against-humanity-and-ethnic-cleansing-rohingya-muslims

Human Rights Watch, HRW (2012). The Government Could Have Stopped This: Sectarian Violence and Ensuing Abuses Burma's Arakan State. https://www.hrw.org/sites/default/files/reports/burma0812webwcover_0.pdf

International Criminal Court, ICC (2011). Elements of Crimes. The International Criminal Court.

International Crisis Group (2016). Myanmar: A New Muslim Insurgency in Rakhine State. Brussels: December 15, 2016.

International Development Committee (2018). Bangladesh and Burma: The Rohingya Crisis. House of Commons International Development Committee, Second Report of Session 2017-19, House of Commons, London.

Islam, N. (1999). The Rohingya Problem. Arakan Rohingya National Organisation (ARNO). Arakan (Burma).

Jones, A. (2010). Genocide: A Comprehensive Introduction. $2^{\text {nd }}$ Edition.

Khin, T. (2014). Is Rohingya Genocide in Burma Being Ignored? The Huffington Post, May 5, 2014.

Kiragu, E., Rosi, A. L., \& Morris, T. (2011). States of Denial a Review of UNHCR's Response to the Protracted Situation of Stateless Rohingya Refugees in Bangladesh. http://www.unhcr.org/4ee754c19.pdf

Klug, F. (2017). AP Finds Evidence for Graves, Rohingya Massacre in Myanmar. AP News.

Kothari, C. R. (2004). Research Methodology: Methods and Techniques ( $2^{\text {nd }}$ Ed.). New Delhi: New Age International (P) Ltd.

Lemkin, R. (1944). Axis Rule in Occupied Europe. Washington, DC.

Lone, W., Oo, K. S., Lewis, S., \& Slodkowski, A. (2017). Massacre in Myanmar: One Grave for 10 Rohingya Men. 2 September 2017, Reuters.

Martin, M. F. (2017). Burma's Brutal Campaign against the Rohingya, Congressional Research Service, $7-5700$.

Mohajan, H. K. (2013). Human Rights in Bangladesh: Stresses on the Period of 2009 to 2012. KASBIT Business Journal, 6, 38-64. 
Mohajan, H. K. (2018). History of Rakhine State and the Origin of the Rohingya Muslims. IKAT: The Indonesian Journal of Southeast Asian Studies, 2(1), 19-46.

Motlagh, J. (2014). These Aren't Refugee Camps, They're Concentration Camps, and People are Dying in Them. The Time, June 17, 2014.

Pitman, T., \& Gecker. J. (2015). Malaysia Migrant Graves Reveal 139 Human Skeletons at Site Where Rohingya Muslims 'Kept by Traffickers'. The Independent.

Rummel, R. J. (1998). Democide Versus Genocide: Which Is What?

Rummel, R. J. (2007). The Blue Book of Freedom: Ending Famine, Poverty, Democide, and War. Nashville, TN: Cumberland House Publishing.

Schabas, W. A. (2009). Genocide in International Law: The Crimes of Crimes. $2^{\text {nd }}$ Edition, Cambridge University Press.

Slim, W. V. (2009). Defeat into Victory: Battling Japan in Burma and India, 1942-1945. London: Pan.

Smith, M. (2006). The Muslim Rohingya of Burma. Kaladan Press.

Stanton, G. (2013). Ten Stages of Genocide. Genocide Watch, 2013. http:/ / www.genocidewatch.org/genocide/tenstagesofgenocide.html

Szurlej, C. (2015). Preventing Genocide against the Rohingya Muslim Minority in Myanmar. Paper Presented at a Conference Entitled "Human Rights, Violence and Dictatorship in Krakow" on 4 December 2015, pp. 90-114.

Taylor, A. (2018). In a First, Burmese Military Admits that Soldiers Killed Rohingya Found in Mass Grave.10 January 2018.

The Guardian (2017). Massacre at Tula Toli: Rohingya Recall Horror of Myanmar Army Attack. 7 September 2017. The Guardian.

The Human Rights Council (2017). The $4^{\text {th }}$ Annual Youth Model United Nations Conference. Background Guide. Regent's University, London.

The Office of the High Commissioner for Human Rights, OHCHR (1951). Convention on the Prevention and Punishment of the Crime of Genocide. The Office of the High Commissioner for Human Rights (OHCHR), 12 January 1951.

Totten, S., Parsons, W. S., \& Charny, I. W. (Eds.) (1997). Century of Genocide: Eyewitness Accounts and Critical Views. New York.

Ullah, A. A. (2011). Rohingya Refugees to Bangladesh: Historical Exclusions and Contemporary Marginalization. Journal of Immigrant \& Refugee Studies, 9(2), 139-161.

UN (1948). Legal Definition of Genocide. United Nations.

UN Guide for Minorities (2017). The United Nations Office of the High Commissioner for Human Rights. http://www.ohchr.org/EN/Issues/Minorities/Pages/MinoritiesGuide.aspx

UN News Centre (2017). UN Human Rights Chief Points to 'Textbook Example of Ethnic Cleansing in Myanmar', $11 \quad$ September 2017. www.un.org/apps/news/story.asp?NewsID=57490\#.Wf8h2Fu0PIU

UNOCHA (2015). Myanmar: Internal Displacement in Rakhine State. http://reliefweb.int/sites/reliefweb.int/files/resources/Affected_Map_IDP_Sites_Rakhine_OC HA_Aug2015_A4.pdf

Veen, R. T. (2005). Myanmar's Muslims: The Oppressed of the Oppressed. Islamic Human Rights Commission, Great Britain.

Wagley, R. (2014). The Quiet Audience: Responsibility to Call for an International Investigation into Crimes against Muslims in Burma. Emory International Law Review, 28(1), $23-61$.

Wright, R., \& Westcott, B. (2017). CNN, September 8, 2017. At Least 270,000 Rohingya Flee Myanmar Violence in 2 Weeks. 
Zarmi, M., \& Cowley, A. (2014). The Slow Burning Genocide of Myanmar's Rohingya. Pacific Rim Law and Policy Journal, 23(3), 683-754.

$--0--$ 